\title{
PENGARUH DISIPLIN DAN MOTIVASI KERJA TERHADAP KINERJA KARYAWAN PT FLUID INDONESIA
}

\author{
Panca Heri Sutanto \\ Eny Ariyanto \\ Email: pancasutanto@yahoo.co.id, eny_ariyanto@yahoo.com \\ Program Studi Magister Manajemen \\ Universitas Mercubuana
}

\begin{abstract}
ABSTRAK
Penelitian ini bertujuan untuk menganalisis pengaruh disiplin dan motivasi kerja terhadap kinerja karyawan PT Fluid Indonesia. Populasi penelitian ini adalah seluruh karyawan PT Fluid Indonesia. Metode sampling yang digunakan adalah metode sensus, sehingga semua anggota populasi yang berjumlah 127 responden tersebut dijadikan sebagai sampel. Metode analisis yang digunakan adalah metode regresi linear berganda. Hasil penelitian membuktikan bahwa disiplin dan motivasi kerja secara parsial berpengaruh positif dan signifikan terhadap kinerja karyawan PT Fluid Indonesia.
\end{abstract}

Kata kunci: Disiplin kerja, motivasi kerja, kinerja karyawan

\section{ABSTRACT}

This study aimed to analyze the influence of discipline and work motivation on employee performance of PT Fluid Indonesia. This study population are employees of PT Fluid Indonesia. Sampling method that used is census method, so all members of the population that consist of 127 respondents are used as samples. Analysis method that used is multiple linear regression method. Results of the study proved that discipline and work motivation partially has positive and significant effect on employee performance of PT Fluid Indonesia.

Keywords: work discipline, work motivation, employee performance

\section{PENDAHULUAN}

PT Fluid Indonesia (PT FI Bogor) mengalami perkembangan yang pesat sejak didirikan tahun 2011 hingga saat ini, baik ditinjau dari segi peningkatan jumlah karyawan maupun peningkatan jumlah produksi. Meskipun demikian, PT Fluid Indonesia masih mempunyai beberapa permasalahan yang perlu diperhatikan. Salah satu permasalahan tersebut adalah masih tingginya biaya produksi aktual dibandingkan dengan target biaya produksi yang telah dianggarkan perusahaan, serta belum optimalnya tingkat kehadiran karyawan.

Realisasi biaya produksi PT Fluid Indonesia disajikan dalam grafik sebagai berikut. 


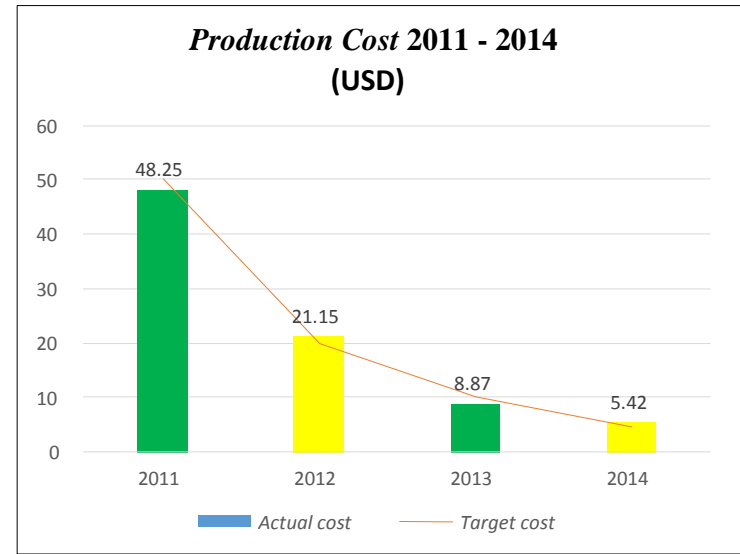

(Sumber: Laporan Departemen Produksi, 2014)

Gambar 1. Biaya Produksi (USD) PT Fluid Indonesia Tahun 2011-2014

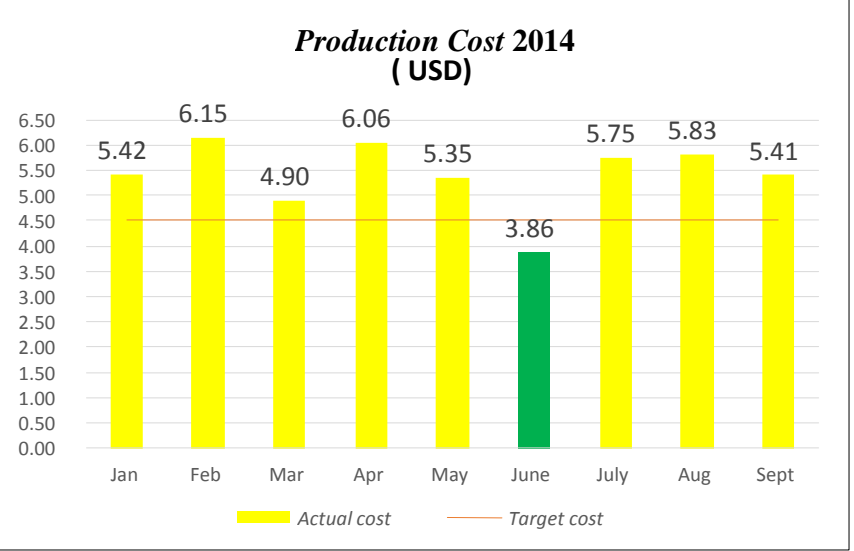

Gambar 2. Biaya Produksi (USD) PT Fluid Indonesia Tahun 2014

Berdasarkan grafik di atas, pada bulan Januari-September 2014, PT Fluid Indonesia mengalami kelebihan biaya produksi dengan rata-rata sebesar 19,2\% dibandingkan dengan target biaya yang telah dianggarkan oleh perusahaan. Grafik di atas dapat mencerminkan bahwa perusahaan belum mencapai kinerja yang optimal karena realisasi biaya produksi perusahaan masih lebih tinggi dari target biaya yang telah dianggarkannya. Permasalahan kinerja ini perlu segera diatasi agar biaya produksi perusahaan di kemudian hari dapat sesuai dengan target biaya produksi yang telah dianggarkannya atau bahkan lebih rendah daripada target biaya produksi tersebut, sehingga pencapaian laba perusahaan di masa yang akan datang dapat dimaksimalisasi. Oleh karena itu, perlu dilakukan penelitian untuk menganalisis faktor-faktor yang dapat meningkatkan kinerja karyawan. Salah satunya adalah disiplin dan motivasi kerja.

Hasil penelitian yang dilakukan oleh Rofi (2012) dan Arsyenda (2013) menunjukkan bahwa disiplin kerja berpengaruh positif dan signifikan terhadap kinerja karyawan. Hal tersebut menunjukkan bahwa semakin tinggi tingkat kedisiplinan kerja karyawan dalam suatu perusahaan, maka semakin tinggi pula kinerja dari karyawan tersebut.

Tingkat kedisiplinan kerja dalam suatu perusahaan dapat diproksikan dengan menggunakan tingkat absensi karyawan dalam perusahaan tersebut. Berikut ini merupakan data absensi tenaga kerja langsung (direct labor) PT Fluid Indonesia tahun 2014. 
Tabel 1. Data Absensi Direct Labor PT Fluid Indonesia Tahun 2014

\begin{tabular}{lrrrrrrrrrr}
\hline Data Absensi & Jan & Feb & Mar & Apr & May & Jun & Jul & Agu & Sept & Total \\
\hline $\begin{array}{l}\text { Direct labor } \\
\text { (person) }\end{array}$ & 98 & 94 & 102 & 102 & 104 & 104 & 103 & 105 & 107 & 919 \\
$\begin{array}{l}\text { Normal work } \\
\text { hours) }\end{array}$ & 16,464 & 15,040 & 17,952 & 17,952 & 18,304 & 18,304 & 18,128 & 14,280 & 14,552 & 150,976 \\
Loss hours & 496 & 549 & 521 & 554 & 605 & 507 & 674 & 608 & 707 & 5,221 \\
Loss hours (\%) & $3.0 \%$ & $3.7 \%$ & $2.9 \%$ & $3.1 \%$ & $3.3 \%$ & $2.8 \%$ & $3.7 \%$ & $4.3 \%$ & $4.9 \%$ & $3.5 \%$ \\
\hline (Sumber: Laporan Departemen Human Resource, 2014) & & & & & & &
\end{tabular}

Berdasarkan tabel di atas, rata-rata loss hours karena ketidakhadiran direct labor adalah 3,5\% atau 8,8 hari per tahun per karyawan pada Januari-September 2014. Sementara itu, ketidakhadiran yang ditargetkan oleh perusahaan hanyalah sebesat 2,9\% atau 7,3 hari per tahun per karyawan. Hal ini menunjukkan bahwa tingkat absensi karyawan masih lebih tinggi daripada target yang telah ditetapkan perusahaan. Selain itu, tingkat ketidakhadiran karyawan PT Fluid Indonesia dapat dikategorikan kurang baik jika dibandingkan dengan tingkat ketidakhadiran di beberapa negara. Berdasarkan survei yang dilakukan oleh CIPD (Chartered Institute of Personnel and Development) pada tahun 2014, angka ketidakhadiran karyawan bidang manufacturing di Inggris Raya hanya sebesar 6,2 hari/tahun. Selain itu, hasil survey yang dilakukan oleh Mercer (2010) untuk Kronos menunjukkan bahwa angka ketidakhadiran karyawan di Amerika Serikat hanya mencapai 5,4 hari/tahun. Jika dibandingkan dengan hasil-hasil survey tersebut, maka tingkat kehadiran di PT Fluid Indonesia pada tahun 2014 dapat dikategorikan cukup tinggi. Tingginya tingkat ketidakhadiran tersebut dapat menjadi salah satu faktor yang menyebabkan kurang optimalnya kinerja karyawan PT Fluid Indonesia pada tahun 2014.

Motivasi kerja juga merupakan salah satu faktor yang dapat mempengaruhi kinerja karyawan. Hal ini sesuai dengan hasil penelitian yang dilakukan oleh Rizwan, et al. (2014) dan Arsyenda (2013) yang menunjukkan bahwa motivasi kerja berpengaruh positif dan signifikan terhadap kinerja karyawan. Dalam kasus ini, hasil wawancara dengan beberapa karyawan menunjukkan bahwa kebijakan perusahaan tentang masalah absensi kurang memotivasi karyawan untuk meningkatkan kehadirannya. Hasil laporan bulanan biaya produksi, absensi, labor cost dan produktivitas pada tahun 2014 menunjukkan bahwa pencapaian terbaik terjadi pada bulan Juni 2014. Hal ini diperkirakan ada hubungannya dengan penilaian kinerja yang tengah dilakukan pada periode itu. Hal tersebut dapat 
menunjukkan bahwa karyawan baru termotivasi untuk meningkatkan kinerjanya pada saat penilaian kerja dilakukan oleh pihak manajemen perusahaan.

Berdasarkan uraian data dan fakta di atas, perlu dilakukan penelitian untuk menganalisis pengaruh disiplin dan motivasi kerja terhadap kinerja karyawan PT Fluid Indonesia.

\section{TINJAUAN PUSTAKA}

\section{Disiplin Kerja}

Disiplin kerja adalah suatu alat yang digunakan para manajer untuk berkomunikasi dengan karyawan agar mereka bersedia untuk mengubah suatu perilaku sebagai suatu upaya untuk meningkatkan kesadaran dan kesediaan seseorang mematuhi semua peraturan perusahaan dan norma-norma sosial yang berlaku (Rivai, 2011). Menurut Hasibuan (2010), disiplin kerja adalah kesadaran dan kesediaan seseorang menaati semua peraturan perusahaan dan norma-norma yang berlaku.

Menurut Levin dalam Helmi (1996), faktor-faktor yang mempengaruhi disiplin kerja terdiri dari faktor kepribadian dan faktor lingkungan. Faktor yang terpenting dalam aspek kepribadian adalah sistem nilai yang berkaitan langsung dengan disiplin, misalnya nilai-nilai yang menjunjung disiplin yang diajarkan oleh orang tua, guru, dan masyarakat yang akan digunakan sebagai acuan bagi penerapan disiplin di tempat kerja. Adapun faktor lingkungan berpengaruh terhadap disiplin kerja karyawan karena disiplin kerja tidak muncul begitu saja, tetapi dibentuk oleh lingkungan yang ada di sekitar karyawan tersebut. Disiplin kerja yang tinggi merupakan suatu proses belajar yang terus-menerus yang dapat dibentuk oleh pemimpin dalam suatu perusahaan dengan menggunakan prinsip-prinsip konsisten, adil, sikap positif dan terbuka.

Nitisemito (2008) berpendapat bahwa beberapa faktor yang mempengaruhi timbulnya perilaku disiplin kerja, yaitu: (1) tujuan pekerjaan dan kemampuan pekerjaan, (2) teladan pimipin, (3) kesejahteraan, (3) keadilan, (4) pengawasan melekat (waskat), (5) sanksi hukum, ketegasan, dan (6) hubungan kemanusiaan.

Menurut Commings (1984) dalam Holil dan Sriyanto (2008), pembentukan perilaku disiplin kerja dapat dilakukan melalui dua cara, yaitu: (1) Preventive discipline, yakni tindakan yang diambil untuk mendorong para pekerja agar mematuhi norma-norma dan aturan-aturan sehingga pelanggaran tidak terjadi; dan (2) Corrective discipline, yaitu suatu tindakan yang mengikuti pelanggaran dari aturan-aturan untuk mengecilkan pelanggaran 
lebih lanjut sehingga perilaku dimasa mendatang diharapkan dapat mematuhi norma-norma peraturan yang berlaku.

Rivai (2011) menyatakan bahwa disiplin kerja memiliki beberapa indikator, yaitu: (1) kehadiran, (2) ketaatan pada peraturan kerja, (3) ketaatan pada standar kerja, (4) kewaspadaan tinggi, dan (5) bekerja etis.

\section{Motivasi Kerja}

Menurut Robbins dan Judge (2008:222), motivasi adalah proses yang menjelaskan intensitas, arah dan ketekunan seseorang individu untuk mencapai suatu tujuan. Ada beberapa konsep motivasi yang dirumuskan para ahli. Teori McClelland menyatakan bahwa terdapat dua motif dalam diri manusia, yaitu motif primer dan motif sekunder. Motif primer adalah motif yang tidak perlu dipelajari, sedangkan motif sekunder atau motif sosial adalah motif yang dipelajari dari pengalaman serta interaksi dengan orang lain. Motif ini dibedakan menjadi tiga motif yaitu: (1) motif untuk berprestasi, (2) motif untuk berafiliasi dan (3) motif untuk berkuasa (Notoatmojo, 2009).

Dalam teori X dan Teori Y yang diungkapkan oleh McGregor, teori X berpandangan dari sifat negatif manusia (klasik), sedangkan teori $\mathrm{Y}$ berpandangan dari sifat positif manusia (modern). Berdasarkan teori ini, pemimpin berkeyakinan bahwa mereka dapat mengarahkan para bawahannya untuk mencapai tujuan organisasi (Notoatmojo, 2009).

Teori Herzberg menyatakan bahwa terdapat dua faktor yang mempengaruhi seseorang dalam tugas atau pekerjaannya, yaitu: (1) faktor penyebab kepuasan (satisfier) atau faktor motivasional, yakni faktor intrinsik yang menyatakan bahwa pencapaian dan pengakuan adalah penyebab utama dari kepuasan dan motivasi; dan (2) faktor kedua, yakni faktor penyebab ketidakpuasan (dissatisfaction) atau faktor hygiene, yakni faktor ekstrinsik, seperti bayaran dan keamanan kerja. Di dalam teori motivasi struktur ganda Herzberg disebutkan bahwa yang termasuk ke dalam motivasi intrinsik (satisfier) adalah (1) pencapaian, (2) pengakuan, (3) pekerjaan itu sendiri, (4) tanggung jawab dan (5) kemajuan dan pertumbuhan. Sementara itu, yang termasuk ke dalam motivasi ekstrinsik (hygiene) adalah (1) pengawasan, (2) kondisi kerja, (3) hubungan interpersonal, (4) bayaran dan keamanan kerja dan (5) kebijakan perusahaan.

Teori heirarki kebutuhan Maslow mengasumsikan bahwa kebutuhan manusia diatur dalam suatu hieraki kepentingan dengan lima tingkatan kebutuhan. Lima tingkatan kebutuhan tersebut, yaitu (1) kebutuhan fisiologis, (2) kebutuhan keamanan, (3) kebutuhan kebersamaan, (4) kebutuhan penghargaan, dan (5) kebutuhan aktualisasi diri. Menurut 
Maslow, kebutuhan di tingkat dasar harus dipenuhi terlebih dahulu sebelum memenuhi kebutuhan tingkatan di atasnya (Moorhead dan Griffin, 2013:90).

\section{Kinerja}

Kinerja adalah hasil kerja yang dapat dicapai oleh seseorang atau sekelompok orang dalam organisasi, sesuai dengan wewenang dan tanggung jawab masing-masing dalam rangka upaya mencapai tujuan organisasi bersangkutan secara legal, tidak melanggar hukum dan sesuai dengan moral maupun etika (Prawirosentono, 2008). Mangkunegara (2011:67) mendefinisikan kinerja sebagai hasil kerja secara kualitas dan kuantitas yang dicapai oleh pegawai dalam melaksanakan tugasnya sesuai tanggung jawab yang diberikan kepadanya.

Menurut Robbins dan Judge (2008) pengukuran kinerja karyawan dapat dilakukan dengan menggunakan enam indikator, yaitu: (1) kualitas, (2) kuantitas, (3) ketepatan waktu, (4) efektivitas, (5) kemandirian, dan (6) komitmen kerja.

\section{Pengaruh Disiplin Kerja terhadap Kinerja}

Disiplin kerja adalah suatu alat yang digunakan para manajer untuk berkomunikasi dengan karyawan agar mereka bersedia untuk mengubah suatu perilaku sebagai suatu upaya untuk meningkatkan kesadaran dan kesediaan seseorang mematuhi semua peraturan perusahaan dan norma-norma sosial yang berlaku (Rivai, 2011). Hal tersebut menunjukkan bahwa semakin tinggi tingkat disiplin kerja yang dimiliki oleh seorang karyawan, maka semakin tinggi pula kesadaran dan kesediaan karyawan tersebut untuk mematuhi semua peraturan dan norma sosial yang berlaku di perusahaan tempatnya bekerja, sehingga semakin baik kinerja dari karyawan tersebut di tempatnya bekerja. Hal ini sejalan dengan hasil penelitian yang dilakukan oleh Arsyenda (2013), Ayer, dkk. (2016) serta Pangarso dan Susanti (2016) yang menemukan bahwa disiplin kerja berpengaruh positif dan signifikan terhadap kinerja karyawan.

$\mathrm{H}_{1}$ : Disiplin kerja berpengaruh positif dan signifikan terhadap kinerja karyawan PT Fluid Indonesia.

\section{Pengaruh Motivasi Kerja terhadap Kinerja}

Menurut Robbins dan Judge (2008:222), motivasi adalah proses yang menjelaskan intensitas, arah dan ketekunan seseorang individu untuk mencapai suatu tujuan. Hal tersebut menunjukkan bahwa semakin tinggi motivasi kerja yang dimiliki oleh seorang karyawan, maka semakin tinggi pula intensitas dan ketekunan karyawan tersebut untuk mencapai tujuan 
dan target yang telah ditetapkan oleh perusahaan, sehingga semakin baik kinerja yang dihasilkan oleh karyawan tersebut. Hal ini sejalan dengan hasil penelitian yang dilakukan oleh Ayer, dkk. (2016), Rizwan, et al. (2014) dan Arsyenda (2013) yang menunjukkan bahwa motivasi kerja berpengaruh positif dan signifikan terhadap kinerja karyawan.

$\mathrm{H}_{2}$ : Motivasi kerja berpengaruh positif dan signifikan terhadap kinerja karyawan PT Fluid Indonesia.

\section{Kerangka Analisis}

Kerangka analisis dalam penelitian ini disajikan dalam gambar sebagai berikut.

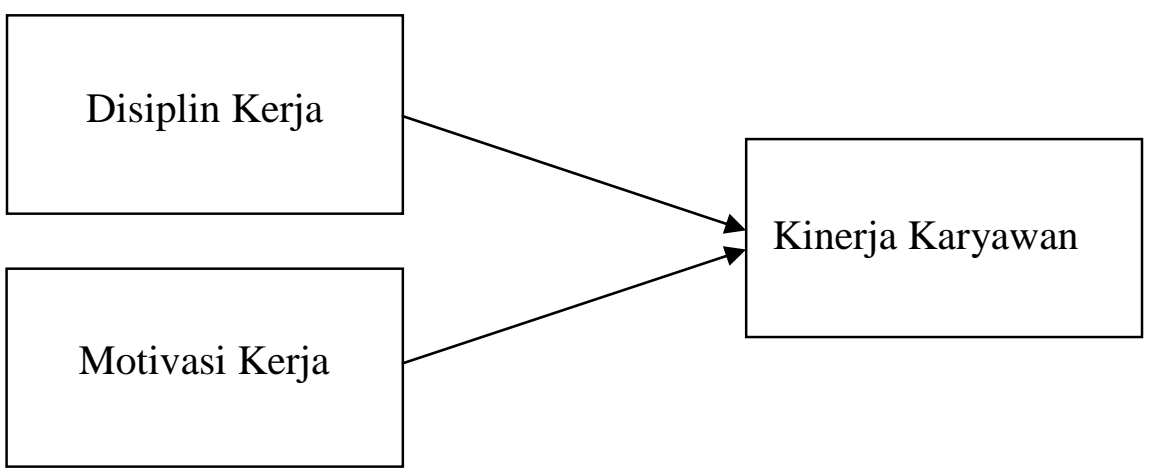

\section{Gambar 3. Model Konseptual Penelitian}

\section{METODE PENELITIAN}

\section{Jenis dan Sumber Data}

Data utama dalam penelitian ini merupakan data primer dari hasil survei/kuesioner yang diberikan kepada karyawan PT Fluid Indonesia. Wawancara juga dilakukan untuk memperkuat, data penelitian. Selain itu, penelitian ini juga menggunakan data sekunder sebagai data pendukung yang diambil dari laporan departemen Human Resource dan departemen produksi PT Fluid Indonesia. Data dari studi literatur digunakan sebagai dasar teori dan penyusunan hipotesis.

\section{Populasi dan Sampel Penelitian}

Populasi penelitian ini adalah seluruh karyawan PT Fluid Indonesia yang telah bekerja minimal satu tahun, baik di level operator maupun manajer. Berdasarkan kriteria tersebut, populasi penelitian ini terdiri dari 127 responden. Oleh karena jumlah populasi yang memenuhi kriteria tidak terlalu banyak, maka metode sampling yang digunakan dalam 
penelitian ini adalah metode sensus, yaitu suatu metode sampling yang menjadikan semua anggota populasi sebagai sampel penelitian.

\section{Definisi Operasional Variabel}

Definisi operasional dari variabel-variabel yang digunakan dalam penelitian ini disajikan dalam tabel berikut.

\section{Tabel 2. Definisi Operasional Variabel}

\begin{tabular}{|c|c|c|c|}
\hline No. & Variabel & Definisi Operasional & Indikator \\
\hline 1. & Kinerja karyawan & $\begin{array}{l}\text { Hasil dari pekerjaan yang } \\
\text { dilakukan oleh seorang } \\
\text { karyawan. }\end{array}$ & $\begin{array}{l}\text { 1. Kuantitas } \\
\text { 2. Kualitas } \\
\text { 3. Ketepatan waktu } \\
\text { 4. Efektivitas } \\
\text { 5. Kemandirian } \\
\text { 6. Komitmen kerja } \\
\text { (Sumber: Robbins dan Judge, 2008) }\end{array}$ \\
\hline 2. & Disiplin kerja & $\begin{array}{l}\text { Kesediaan karyawan untuk } \\
\text { mematuhi semua peraturan } \\
\text { dan norma yang diterapkan } \\
\text { dalam perusahaan } \\
\text { tempatnya bekerja. }\end{array}$ & $\begin{array}{l}\text { 1. Kehadiran } \\
\text { 2. Ketaatan pada peraturan kerja } \\
\text { 3. Ketaatan pada standar kerja } \\
\text { 4. Kewaspadaan tinggi } \\
\text { 5. Etika kerja } \\
\text { (Sumber: Rivai, 2011) }\end{array}$ \\
\hline 3. & Motivasi kerja & $\begin{array}{l}\text { Suatu hal yang mendorong } \\
\text { karyawan untuk } \\
\text { melaksanakan } \\
\text { pekerjaannya dengan baik. }\end{array}$ & $\begin{array}{l}\text { 1. Motivasi intrinsik } \\
\text { a. Pencapaian } \\
\text { b. Pengakuan } \\
\text { c. Pekerjaan itu sendiri } \\
\text { d. Tanggung jawab } \\
\text { e. Kemajuan dan pertumbuhan } \\
\text { 2. Motivasi ekstrinsik } \\
\text { a. Pengawasan } \\
\text { b. Kondisi kerja } \\
\text { c. Hubungan interpersonal } \\
\text { d. Bayaran dan keamanan kerja } \\
\text { e. Kebijakan perusahaan } \\
\text { (Sumber: Herzberg dalam Munandar, } \\
\text { 2006:331) }\end{array}$ \\
\hline
\end{tabular}

\section{Metode Analisis}

Metode analisis penelitian ini adalah metode analisis regresi linier berganda yang digunakan untuk menganalisis pengaruh variabel bebas terhadap variabel terikat. Uji t digunakan untuk menguji pengaruh variabel bebas terhadap variabel terikat secara parsial. Adapun uji f digunakan untuk menguji pengaruh variabel bebas terhadap variabel terikat 
secara simultan. Sementara itu, uji koefisien determinasi $\left(\mathrm{R}^{2}\right)$ digunakan untuk menguji besarnya kontribusi variabel-variabel bebas dalam mempengaruhi variabel terikat.

\section{HASIL PENELITIAN}

\section{Profil Responden}

Jumlah responden yang telah mengisi kuesioner secara lengkap adalah 119 orang dari 127 karyawan yang menjadi sampel penelitian atau 93.7\% dari jumlah sampel tersebut. Komposisi responden terdiri dari $78.2 \%$ laki-laki dan $21.8 \%$ perempuan. Hal ini dikarenakan sebagian besar pekerjaan operator merupakan pekerjaan fisik yang dilakukan oleh karyawan laki-laki.

Berdasarkan umurnya, $89.8 \%$ responden berusia di bawah 30 tahun, bahkan 68\% berusia di bawah 25 tahun. Hal ini dapat diartikan bahwa sebagian besar responden mempunyai potensi masa depan produktif yang panjang di perusahaan.

Berdasarkan tingkat pendidikannya, 91.6\% responden berpendidikan sekolah menengah atau dibawahnya, sedangkan $8.4 \%$ responden lainnya berpendidikan perguruan tinggi. Hal ini dapat diartikan bahwa sebagian besar reponden berada di level pelaksana kebijakan, sedangkan sebagian kecil lainnya merupakan penentu/pemikir kebijakan.

Berdasarkan golongan/jenis pekerjaannya, $67.2 \%$ responden merupakan direct labor, sedangkan 32.8\% sisanya merupakan indirect labor. Artinya, sebagian besar responden merupakan karyawan yang berkaitan langsung dengan proses produksi.

\section{Deskripsi Statistik Variabel Penelitian}

Secara umum, variabel-variabel yang diteliti yaitu disiplin kerja, motivasi kerja dan kinerja karyawan di PT Fluid Indonesia memiliki nilai yang cukup baik. Variabel disiplin kerja mempunyai nilai rata-rata sebesar 4,42, motivasi kerja mempunyai nilai rata-rata sebesar 4.27 dan variabel kinerja mempunyai nilai rata-rata sebesar 4,31. Nilai rata-rata yang berada di atas angka empat dapat mencerminkan bahwa responden cenderung sering menyetujui hal-hal yang bersifat positif dari kuesioner yang diajukan kepadanya.

\section{Uji Kualitas Instrumen Penelitian}

Kualitas kuesioner yang digunakan dapat diketahui dari hasil pengolahan data untuk 30 sampel pertama. Dari 19 butir kuesioner disiplin kerja, 18 butir memiliki nilai sig. antara 0,000 - 0,029 sehingga dapat dikatakan valid karena nilai sig. $<0,05$. Sementara itu, 1 butir lainnya mempunyai nilai sig. sebesar 0,457 sehingga dikatakan tidak valid karena nilai sig > 
0,05. Satu butir kuesioner yang tidak valid ini tetap diikutkan dalam kuesioner dan diuji lagi pada total sampel akhir. Pada pengujian untuk 119 sampel, 1 butir yang semula tidak valid tersebut menjadi valid karena memiliki nilai sig. $<0,05$, yaitu sebesar 0,000. Hasil uji validitas juga menunjukkan bahwa 16 butir kuesioner motivasi kerja dan 12 butir kuesioner kinerja memiliki nilai sig. $<0,05$, sehingga semua butir kuesioner tersebut bersifat valid.

Adapun hasil uji reliabilitas menunjukkan bahwa semua butir kuesioner bersifat reliabel karena memiliki nilai cronbach's alpha > 0,60, yaitu antara 0,845 - 0,871.

\section{Uji Asumsi Klasik}

Uji multikolinearitas menghasilkan nilai koefisien korelasi pearson antara disiplin kerja dan motivasi kerja sebesar 0,309. Oleh karena nilai tersebut berada di bawah 0,95, maka tidak terjadi multikolinieritas dalam model penelitian ini (Nurhayati, 2015).

Adapun hasil uji heteroskedastisitas menunjukkan bahwa tidak terjadi heteroskedastisitas dalam model regresi ini karena tidak terlihat adanya pola-pola tertentu pada diagram pencar (Nurhayati, 2015).

Dalam penelitian ini, uji normalitas dilakukan dengan menggunakan histogram, grafik normal P-Plot dan uji Kolmogorov-Smirnov. Hasil uji normalitas dengan menggunakan histogram menunjukkan bahwa data menyebar di sekitar pola garis histogram, sehingga data dapat dikatakan terdistribusi normal. Dengan menggunakan grafik normal P-Plot, terlihat bahwa sebaran titik-titik berada di sekitar garis diagonal, sehingga data dikatakan terdistribusi normal (Ulwan, 2014). Dengan menggunakan uji Kosmogorov-Smirnov, diperoleh nilai asymp. sig. (2-tailed) sebesar 0,200 sehingga data dikatakan terdistribusi normal karena memiliki nilai asymp. sig. (2-tailed) $>0,05$.

Hasil keseluruhan uji asumsi klasik tersebut menunjukkan bahwa data hasil kuesinoner dapat dianalisis dengan menggunakan metode regresi linear berganda yang telah dirumuskan sebelumnya. 


\section{Analisis Regresi Linear Berganda dan Pengujian Hipotesis}

Hasil uji regresi linear berganda disajikan dalam tabel sebagai berikut.

Tabel 3. Hasil Uji Regresi Linear Berganda

\begin{tabular}{|l|c|c|c|c|c|}
\hline \multirow{2}{*}{ Model } & \multicolumn{2}{|c|}{$\begin{array}{c}\text { Unstandardized } \\
\text { Coefficients }\end{array}$} & $\begin{array}{c}\text { Standardized } \\
\text { Coefficients }\end{array}$ & \multirow{2}{*}{ T } & \multirow{2}{*}{ Sig. } \\
\cline { 2 - 4 } & B & $\begin{array}{c}\text { Std. } \\
\text { Error }\end{array}$ & Beta & & \\
\hline (Constant $)$ & 2,931 & 3,751 & & 0,781 & 0,436 \\
\hline Disiplin Kerja & 0,419 & 0,055 & 0,572 & 7,580 & 0,000 \\
\hline Motivasi Kerja & 0,116 & 0,059 & 0,149 & 1,977 & 0,050 \\
\hline
\end{tabular}

(Sumber: Data diolah, 2015)

Berdasarkan hasil uji regresi linear berganda di atas, persamaan regresi linear berganda dalam penelitian ini adalah sebagai berikut.

$$
Y=2,931+0,419 X_{1}+0,116 X_{2}
$$

Keterangan:

$$
\begin{array}{ll}
\mathrm{Y} & =\text { Kinerja karyawan } \\
\mathrm{X}_{1} & =\text { Disiplin kerja } \\
\mathrm{X}_{2} & =\text { Motivasi kerja }
\end{array}
$$

Berdasarkan tabel 3, variabel disiplin kerja memiliki nilai $t_{\text {hitung }}$ sebesar 7,580 dengan sig. sebesar 0,000 yang lebih kecil daripada 0,05 , sehingga $\mathrm{H}_{0}$ ditolak dan $\mathrm{H}_{1}$ diterima. Hal tersebut menunjukkan bahwa disiplin kerja berpengaruh positif dan signifikan terhadap kinerja karyawan PT Fluid Indonesia.

Variabel motivasi kerja memiliki nilai $t_{\text {hitung }}$ sebesar 1,977 dengan sig. sebesar 0,050, sehingga $\mathrm{H}_{0}$ ditolak dan $\mathrm{H}_{2}$ diterima. Hal tersebut menunjukkan bahwa motivasi kerja berpengaruh positif dan signifikan terhadap kinerja karyawan PT Fluid Indonesia.

\section{Uji Kelayakan Model (Uji F)}

Hasil pengujian kelayakan model disajikan dalam tabel sebagai berikut.

Tabel 4. Hasil Uji F

\begin{tabular}{|l|c|r|r|r|r|}
\hline \multicolumn{1}{|c|}{ Model } & $\begin{array}{c}\text { Sum of } \\
\text { Squares }\end{array}$ & df & $\begin{array}{c}\text { Mean } \\
\text { Square }\end{array}$ & F & Sig. \\
\hline Regression & 1933.328 & 2 & 966.664 & 39.039 & 0.000 \\
Residual & 2872.338 & 116 & 24.762 & & \\
Total & 4805.666 & 118 & & & \\
\hline
\end{tabular}

(Sumber: Data diolah, 2016) 
Berdasarkan tabel di atas, diperoleh nilai sig. sebesar 0,000 yang lebih kecil daripada 0,05 . Hal tersebut menunjukkan bahwa disiplin kerja dan motivasi kerja secara bersama-sama berpengaruh positif dan signifikan terhadap kinerja karyawan PT Fluid Indonesia. Berdasarkan hal tersebut, model regresi yang digunakan dalam penelitian ini bersifat layak.

\section{Uji Koefisien Determinasi}

Hasil uji koefisien determinasi disajikan dalam tabel sebagai berikut.

Tabel 5. Hasil Uji Koefisien Determinasi

\begin{tabular}{|c|r|r|r|}
\hline $\mathbf{R}$ & $\begin{array}{c}\mathbf{R} \\
\text { Square }\end{array}$ & $\begin{array}{c}\text { Adjusted R } \\
\text { Square }\end{array}$ & $\begin{array}{l}\text { Std. Error of } \\
\text { the Estimate }\end{array}$ \\
\hline 0.634 & 0.402 & 0.392 & 4.97610 \\
\hline
\end{tabular}

(Sumber: Data diolah, 2015)

Berdasarkan tabel di atas, dapat diketahui bahwa besarnya nilai koefisien determinasi (adjusted $R$ square) adalah 0,392. Hal tersebut menunjukkan bahwa variabel disiplin kerja dan motivasi kerja memberikan kontribusi sebesar 39,2\% dalam mempengaruhi kinerja karyawan PT Fluid Indonesia, sedangkan 60,8\% sisanya dipengaruhi oleh variabel-variabel lain yang tidak dianalisis dalam penelitian ini.

\section{Pembahasan Hasil Penelitian}

Hasil penelitian ini menunjukkan bahwa disiplin kerja dan motivasi kerja secara parsial berpengaruh positif dan signifikan terhadap kinerja karyawan PT Fluid Indonesia. Hasil penelitian ini sejalan dengan hasil penelitian yang dilakukan oleh Arsyenda (2013) serta Ayer, dkk. (2016) yang menunjukkan bahwa disiplin kerja dan motivasi kerja secara parsial berpengaruh positif dan signifikan terhadap kinerja karyawan.

Berdasarkan tabel 2, besarnya nilai beta untuk variabel disiplin kerja adalah 0,419, sedangkan besarnya nilai beta untuk motivasi kerja adalah 0,116. Hal ini mengindikasikan bahwa faktor disiplin kerja lebih dominan pengaruhnya terhadap kinerja daripada faktor motivasi kerja. Nilai beta sebesar 0,419 untuk variabel disiplin kerja menunjukkan bahwa pengaruh disiplin kerja terhadap kinerja berada pada level moderat karena berada di antara 0,400 0 - 0,599 (Sugiyono, 2013). Besarnya nilai beta sebesar 0,116 untuk variabel motivasi kerja menunjukkan bahwa pengaruh motivasi kerja terhadap kinerja berada pada level sangat lemah karena berada di antara 0,000 - 0,199 (Sugiyono, 2013).

Hubungan antara disiplin kerja, motivasi kerja dan kinerja ditunjukkan oleh matriks korelasi pada tabel berikut 
Tabel 6. Matriks Korelasi Antarvariabel Penelitian

\begin{tabular}{|c|c|c|c|c|c|c|c|c|}
\hline $\begin{array}{c}\text { Korelasi } \\
\text { Product } \\
\text { Moment }\end{array}$ & $\begin{array}{c}\text { Disiplin } \\
\text { Kerja }\end{array}$ & $\begin{array}{c}\text { Dimensi } \\
\text { Kehadiran }\end{array}$ & $\begin{array}{c}\text { Dimensi } \\
\text { Ketaatan }\end{array}$ & $\begin{array}{c}\text { Dimensi } \\
\text { Kewaspadaan }\end{array}$ & $\begin{array}{c}\text { Dimensi } \\
\text { Etika } \\
\text { Kerja }\end{array}$ & $\begin{array}{c}\text { Motivasi } \\
\text { Kerja }\end{array}$ & $\begin{array}{c}\text { Dimensi } \\
\text { Motivasi } \\
\text { Intrinsik }\end{array}$ & $\begin{array}{c}\text { Dimensi } \\
\text { Motivasi } \\
\text { Ekstrinsik }\end{array}$ \\
\hline Kinerja & 0,618 & 0,447 & 0,517 & 0,485 & 0,566 & 0,326 & 0,371 & 0,235 \\
\hline $\begin{array}{c}\text { Dimensi } \\
\text { Kuantitas }\end{array}$ & 0,475 & 0,317 & 0,480 & 0,346 & 0,369 & 0,268 & 0,257 & 0,236 \\
\hline $\begin{array}{c}\text { Dimensi } \\
\text { Kualitas }\end{array}$ & 0,499 & 0,300 & 0,406 & 0,481 & 0,411 & 0,196 & 0,296 & $\underline{0,075}$ \\
\hline $\begin{array}{c}\text { Dimensi } \\
\text { Tepat Waktu }\end{array}$ & 0,488 & 0,367 & 0,439 & 0,247 & 0,456 & 0,227 & 0,213 & 0,205 \\
\hline $\begin{array}{c}\text { Dimensi } \\
\text { Efektivitas }\end{array}$ & 0,250 & $\underline{0,151}$ & $\underline{0,163}$ & 0,191 & 0,338 & $\underline{0,063}$ & 0,187 & $\underline{0,059}$ \\
\hline $\begin{array}{c}\text { Dimensi } \\
\text { Kemandirian }\end{array}$ & 0,520 & 0,443 & 0,429 & 0,425 & 0,395 & 0,272 & 0,333 & $\underline{0,175}$ \\
\hline $\begin{array}{c}\text { Dimensi } \\
\text { Komitmen } \\
\text { Kerja }\end{array}$ & 0,541 & 0,341 & 0,396 & 0,442 & 0,609 & 0,346 & 0,334 & 0,305 \\
\hline
\end{tabular}

(Sumber: Data diolah, 2015)

Berdasarkan tabel di atas, dapat dilihat bahwa sebagian besar dimensi dari variabel disiplin kerja memiliki koefisien korelasinya yang berada pada kisaran 0,400 - 0,599, sehingga disiplin kerja dan kinerja memiliki hubungan pada level moderat (Sugiyono, 2013). Hubungan yang paling lemah berada pada dimensi kehadiran yang ditunjukkan dengan koefisien korelasi sebesar 0,447. Hal ini dikarenakan hanya karyawan direct labor saja yang diwajibkan datang tepat waktu oleh PT Fluid Indonesia dengan pengontrolan absensi yang dilakukan menggunakan mesin absensi otomatis. Sementara itu, karyawan indirect labor lebih ditekankan pada penyelesaian pekerjaan, bukan kedatangan secara fisik di tempat kerja. Hal ini sesuai dengan budaya kerja yang dikembangkan di perusahaan, yaitu kebebasan yang bertanggung jawab, yakni tidak terpaku pada jam kerja dan pengawas jam kerja (responsible freedom - no time clocks or clock watchers).

Etika kerja menjadi dimensi yang memiliki pengaruh yang paling tinggi terhadap kinerja karyawan.Hal ini berkaitan dengan budaya kerja yang sedang dikembangkan dalam perusahaan tersebut, yaitu kebebasan bertanggungjawab, transparansi, integritas dan kesetaraan. Prinsip tersebut menekankan pentingnya memiliki karyawan yang berintegritas tinggi. Pada kenyataannya, hasil kuesioner menunjukkan bahwa 52.1\% karyawan terkadang masih sungkan/enggan menegur rekan kerjanya yang melakukan pelanggaran. Hal ini menjadi hal yang harus segera dibenahi oleh perusahaan.

Berdasarkan tabel di atas, variabel motivasi kerja dan kinerja memiliki koefisien korelasi sebesar 0,326. Hal tersebut menunjukkan bahwa motivasi kerja dan kinerja memiliki hubungan yang lemah/kurang karena berada di interval 0,200 - 0,399 (Sugiyono, 2013). Menurut Singh (2010), motivasi kerja akan meningkatkan produktifitas (kinerja) karyawan secara perseorangan maupun per kelompok. Akan tetapi, ketidaksesuaian bisa saja terjadi, 
sehingga karyawan berproduktivitas rendah meskipun bermotivasi tinggi atau sebaliknya, karyawan berproduktivitas tinggi meskipun bermotivasi rendah. Ketidaksesuaian ini dapat disebabkan oleh kerja yang tidak fokus, terjadinya perubahan, adanya aktivitas yang berorientasi pada hasil baru, model kerja yang berprinsip“just do it”, adanya pengawasan yang ketat dan adanya target kerja sangat jelas (Singh, 2010).

Menurut manajer produksi PT Fluid Indonesia, pada saat penelitian dilakukan, sedang terjadi transisi atau perubahan dari produk lama ke produk baru. Pada saat transisi ini sebagian karyawan diharuskan mempelajari produk baru, termasuk beberapa proses baru. Meskipun begitu, karyawan tersebut harus tetap memproduksi produk yang lama. Selain itu, di dalam aktivitas-aktivitas yang berhubungan dengan produk baru, banyak dilakukan percobaan (trial and error). Proses tertentu bahkan sangat bergantung pada keputusankeputusan yang dikeluarkan oleh pihak kantor pusat di Amerika Serikat, sehingga karyawan di PT Fluid Indonesia hanya menjalankan hasil keputusannya saja (just do it). Berdasarkan uraian di atas, lemahnya hubungan antara motivasi kerja dan kinerja kemungkinan terjadi karena sebagian karyawan harus berbagi perhatian (tidak fokus) dalam melaksanakan pekerjaannya, lebih berorientasi kepada hasil yang baru dan bekerja dengan model "just do $i t^{\prime \prime}$.

Berdasarkan tabel 5, koefisien korelasi hubungan antara motivasi intrinsik dan kinerja lebih besar daripada koefisien korelasi hubungan antara motivasi ekstrinsik dan kinerja $(0,371>0,235)$. Artinya, pengaruh motivasi intrinsik terhadap kinerja karyawan lebih besar daripada pengaruh motivasi ekstrinsik terhadap kinerja karyawan. Salah satu indikator motivasi kerja yang berpengaruh tidak signifikan adalah kebijakan perusahaan.

\section{KESIMPULAN DAN SARAN}

\section{Kesimpulan}

Berdasarkan hasil penelitian dan pembahasan yang telah diuraikan sebelumnya, dapat diambil kesimpulan sebagai berikut.

1. Disiplin kerja berpengaruh positif, signifikan dan moderat terhadap kinerja karyawan PT Fluid Indonesia.

2. Motivasi kerja berpengaruh positif, signifikan dan sangat lemah terhadap kinerja karyawan PT Fluid Indonesia. 


\section{Saran}

Berdasarkan hasil penelitian, pembahasan dan kesimpulan, maka perusahaan dapat mempertimbangkan saran berikut ini.

1. Perusahaan perlu membuat suatu program dan mengambil suatu tindakan untuk meningkatkan kesadaran karyawan tentang disiplin kerja, terutama pada aspek etika kerja.

2. Perusahaan perlu mengkaji dan memperbarui kebijakan-kebijakan yang berkaitan dengan kinerja karyawan agar kebijakan tersebut dapat menjadi alat bagi perusahaan untuk meningkatkan kinerja karyawannya.

3. Perlu diadakan penelitian lanjutan untuk menganalisis variabel-variabel lain yang berpengaruh signifikan terhadap kinerja karyawan.

\section{DAFTAR PUSTAKA}

Arsyenda, Y. 2013. Pengaruh Motivasi Kerja dan Disiplin Kerja terhadap Kinerja PNS: Studi Kasus pada BAPPEDA Kota Malang. Jurnal Ilmiah Fakultas Ekonomi dan Bisnis Universitas Brawijaya.

Ayer, J.E., L.R.J. Pangemanan dan Y.P.I. Rori. 2016. Pengaruh Motivasi dan Disiplin Kerja terhadap Kinerja Pegawai pada Dinas Pertanian Kabupaten Supiori. AgriSosioEkonomi Unsrat. 12(3A): 27-46.

Chartered Institute of Personnel and Development. 2014. Annual survey report 2014: Absence Management. London.

Hasibuan, M.S.P. 2010. Manajemen Sumber Daya Manusia. Bumi Aksara. Jakarta.

Helmi, A.F. 1996. Disiplin Kerja. Buletin Psikologi. 4(2): 32-42.

Holil, M. dan A. Sriyanto. 2008. Pengaruh Motivasi dan Disiplin Kerja terhadap Kinerja Pegawai: Studi Kasus Kantor Pelayanan Pajak Badan Usaha Milik Negara. Jurnal Universitas Budi Luhur.

Kronos. 2010. SHRM Annual Conference, June 28, 2010: Unplanned Absence Costs Organizations 8.7 Percent of Payroll, More than Half the Cost of Healthcare, According to New Mercer Study Sponsored by Kronos. http://www.kronos.com/pr/unplanned-absence-costs-organizations-over-8-percent-ofpayroll.aspx. 15 Oktober 2014 (21:27).

Mangkunegara, A.A.A.P. 2011. Manajemen Sumber Daya Manusia Perusahaan. Remaja Rosdakarya Offset. Bandung.

Moorhead, G. dan R.W. Griffin. 2013. Organizational Behavior: Managing People and Organizations. Cengage Learning. Mason. Terjemahan. 2013. Perilaku Organisasi: Manajemen Sumber Daya Manusia dan Organisasi. Salemba Empat. Jakarta. 
Munandar, A.S. 2006. Psikologi Industri dan Organisasi. UI-Press. Jakarta.

Nitisemito, A.S. 2008. Manajemen Personalia. Ghalia Indonesia. Jakarta.

Notoatmodjo, S. 2009. Pengembangan Sumber Daya Manusia. Rineka Cipta. Jakarta.

Nurhayati, M. 2015. Pelatihan Pengolahan Data Menggunakan Program SPSS. Universitas Mercubuana. Jakarta.

Pangarso, A. dan P.I. Susanti. 2016. Pengaruh Disiplin Kerja terhadap Kinerja Pegawai di Biro Pelayanan Sosial Dasar Sekretariat Daerah Provinsi Jawa Barat. Jurnal Manajemen Teori dan Terapan. 9(2): 145-160.

Prawirosentono, S. 2008. Manajemen Sumber Daya Manusia: Kebijakan Kinerja Karyawan. Penerbit BPFE. Yogyakarta.

Rivai, V. 2011. Performance Appraisal: Sistem yang Tepat untuk Menilai Kinerja Karyawan dan Meningkatkan Daya Saing Perusahaan. Raja Grafindo Persada. Jakarta.

Rizwan, M., M. Tariq, R. Hassan dan A. Sultan. 2014. A Comparative Analysis of the Factors Effecting the Employee Motivation and Employee Performance in Pakistan. International Journal of Human Resource Studies. 4(3): 35-49.

Robbins, S.P. dan T.A. Judge. 2008. Organizational Behavior. $13^{\text {th }}$ Ed. PHI Learning Private Limited. New Delhi. Terjemahan B. Molan. 2009. Perilaku Organisasi. Edisi 16. Salemba Empat. Jakarta.

Rofi, A.N. 2012. Pengaruh Disiplin Kerja dan Pengalaman Kerja terhadap Prestasi Kerja Karyawan pada Departemen Produksi PT Leo Agung Raya Semarang. Jurnal Ilmu Manajemen dan Akuntansi Terapan. 3(1).

Singh, P. 2010. Increasing Productivity with Motivation in the Workplace. Abhinav: National Monthly Refereed Journal of Research in Commerce and Management. 2(6): 27-32.

Sugiyono. 2013. Statistika untuk Penelitian. Alfabeta. Bandung. 